\title{
The Distribution of Pupils with Muslim Religio-Cultural Backgrounds in Danish Schools
}

\author{
Mark Sedgwick
}

\begin{abstract}
Forskningsnotatet redegor for fordelingen af elever med muslimske religioskulturelle baggrunde $i$ de danske skoler. Religios-kulturel baggrund er tilskrevet elever med ikke-dansk herkomst på baggrund af national oprindelse ifolge statweb.uni-c.dk. Religios-kulturel baggrund er ikke det samme som religion, men indikerer alligevel, hvor byppige forskellige typer forhold er. Notatet viser, at langt de fleste danske skoler har fä eller ingen elever med muslimsk baggrund, og at skoler med mange muslimske elever er yderst usadvanlige. Langt storstedelen af elever med dansk oprindelse gär säledes i skole med andre elever med dansk oprindelser. Relativt fà elever med oprindelse i muslimske lande gär på denne type skole. Mange går på skoler, der har et hojt antal eller et flertal af elever med muslimske religios-kulturelle baggrunde.
\end{abstract}

Relatively little is known of the distribution of Muslim pupils in Danish schools. There have been various studies of Danish schools with Muslim minorities or even majorities, and various studies of Muslim pupils in Danish schools, and these have provided important understandings of what can happen to schools, pupils and teachers under particular conditions (see the introduction to this special issue). What has not been clear, however, is how frequent those conditions are, and so how significant particular conditions and processes are for Danish society or for Danish Muslims or non-Muslims. The present research note seeks to clarify this.

This research note gives a picture of the distribution in Danish schools of pupils with Muslim religio-cultural backgrounds as of 2009. It shows that the vast majority of Danish schools have few or no pupils with Muslim religio-cultural backgrounds, and that schools with large populations of pupils with Muslim religio-cultural backgrounds are extremely unusual. The vast majority of pupils of Danish origin thus go to schools attended overwhelmingly by other pupils of Danish origin. Relatively few pupils with origins in Muslim countries, however, go to this type of school. Very many go to schools that have large populations of pupils with Muslim religio-cultural backgrounds, or even majorities with these backgrounds. In the case of Muslim-majority "free schools" (friskoler), ${ }^{1}$ this can be assumed to reflect parental choice. In the case of state schools (folkeskoler), ${ }^{2}$ however, it probably reflects residential

\footnotetext{
${ }^{1}$ Friskoler are state-funded private schools that may charge a small top-up fee and are "free" in the sense of having somewhat more freedom than state schools in matters of curriculum, ethos, etc.

${ }^{2}$ Folkeskoler are literally "people's schools." They are the mainstream state-funded school system.
} 
clustering more than parental choice, though of course residential clustering can also result from choice, as well as from economic factors.

\section{Religio-Cultural Background and Nationality of Origin}

This note deals not with Muslim or Christian religious belief or practice (which would be extremely difficult to assess on a national scale), but with religio-cultural background, which can be understood as one of many dimensions of religiosity and which can be deduced from nationality of origin. Data concerning nationality of origin for the Danish school system was at one point publicly available, and was used as the basis of this research note.

Religio-cultural background is of course not the same as religion. Many Danes, for example, describe themselves as "cultural Christians," by which they usually mean that they do not consider themselves to be devout, practicing, believing Christians. Even devout, practicing, believing Christians, however, are also cultural Christians. Religio-cultural background, then, includes both the devout and the non-practicing. Devotion, belief and practice are hard to quantify, and generally vary depending on time and place, even for a single individual. Religiocultural background, by contrast, is easier to quantify and is less variable. It is also important: religion is about identity as well as devotion, belief and practice, and religious identity is generally determined by religiocultural background, though the relative importance of various sources of identity is of course a different matter.

A pupil with a Muslim religio-cultural background, then, can be expected to be Muslim rather than Christian or Buddhist in their religious identity, and culturally Muslim at least in the way that a "cultural Christian" is culturally Christian: that is, more culturally Muslim than culturally Christian or Buddhist. Some pupils with a Muslim religiocultural background will be devout, practicing, and believing Muslims, and some will not. How many are devout, practicing, and believing is a question on which this research note does not seek to cast light.

Religio-cultural background is not the same as religion, then, but is a lot easier to measure. A pupil of Danish origin or Swedish nationality of origin recorded by the Danish ministry of education can be assumed to have a non-Muslim religio-cultural background, while a pupil with a Turkish or Palestinian nationality of origin can be assumed to have a Muslim religio-cultural background. In reality, these assumptions will sometimes be wrong. Some pupils of Danish or Swedish origin have Muslim family backgrounds, and some pupils of Turkish or Pakistani origin may have non-Muslim family backgrounds, as both Turkey and Pakistan have small Christian minorities. In general, however, the method of deducing religio-cultural background from origin can be expected to be reasonably accurate. It certainly gives a better picture of the distribution in Danish schools of pupils with Muslim backgrounds than any other available technique.

The ministry of education's data for nationality of origin for pupils of non-Danish origin for the 2008-09 school year was publicly available in 2010 , and is the data on which this note is based. This data is no longer publicly available, and comparable data for later years has not been made available. What is available now is data by school for Danish and non- 
Danish origin without nationality of origin. The distribution of Danish and non-Danish origin has not changed significantly between 2009 and 2013 , the most recent year for which data is currently available. ${ }^{3}$ Data for 2009, then, is still relevant in 2014.

\section{Data}

The data concerning nationality of origin for the Danish school system that was used as the basis of this research note presented certain problems. These problems and the steps taken to address them are described below.

Data was drawn from the ministry of education database held at statweb.uni-c.dk. It was then processed and analyzed on a standard spreadsheet assigning religio-cultural background on the basis of what is known of the majority religious composition of each country of origin. This can be expected to produce some overstatement of Muslim religiocultural background, or "Muslim background," the term that will now be used for the sake of brevity. While it is possible but unlikely that a pupil of Turkish origin will have a Christian background, rather more Palestinians or Iraqis than Turks are Christian, and Arab Christians have in recent centuries been especially likely to emigrate. All pupils of Pakistani or Iraqi origin, however, were assigned a Muslim background.

A second source of inaccuracy was the definition of origin used by the ministry, which assigned Danish origin to any pupil with at least one parent born in Denmark, probably understating pupils with Muslim backgrounds somewhat. At the Qaumi International School (the name has been changed), a free school in Copenhagen attended otherwise only by pupils of Pakistani origin with a few of Afghan and British origin, 18 pupils were classed as of Danish origin, as were 42 pupils at the Tahrir School (the name has been changed), another free school in Copenhagen otherwise attended otherwise only by pupils of Arab origin. The pupils in question presumably had one parent born in Denmark, but to judge by their parents' choice of school were evidently being brought up in a Muslim family. This source of inaccuracy tends to understate the number of pupils of Muslim background, since the method used assumes that it is impossible to have both a Danish origin (as defined by the ministry of education) and a Muslim background, while in reality this is not the case. The pupils at the Qaumi International School with British origin, incidentally, can be assumed to have had British-Pakistani origins, given the school they attended. As has been noted above, nationality is not always a reliable guide to religio-cultural background, even if it usually is.

Some degree of inaccuracy also derives from the ministry of education's suppression of detailed data relating to groups of pupils smaller than five "for considerations of discretion." This means that the national origin of some pupils of non-Danish origin in many schools was not identified, and that the schools attended by some pupils of each national origin were thus also not identified. Since it was data relating to small groups of pupils that was suppressed, data relating to pupils of

\footnotetext{
${ }^{3}$ According to data taken from statweb.uni-c.dk in 2014, distribution of pupils with nonDanish origins in state schools and private schools in 2013 was almost identical to 2009.
} 
Turkish origin (of whom there are many) was more complete than data relating to pupils of US origin (of whom there are few). The state schools attended by all but 540 of 10,028 pupils of Turkish origin were thus identified, while only six of 126 pupils of US origin were associated with a particular state school, since only one state school in Denmark has more than four American pupils (it has six). The other 120 American pupils attend school in groups of four or less, and so were not identified.

This problem has no impact on total numbers reported: we know that there were 126 pupils of US origin in Danish state schools in 2009, even if we do not know which state schools 120 of them were attending. It does have an impact on certain schools, however. The Strand School (the name has been changed), for example, had 484 pupils of Danish origin and 44 of non-Danish origin. Twelve of the 44 were identified as of Iraqi origin and so could be assigned a Muslim background, while six were identified as of Vietnamese origin and so could be assigned a nonMuslim background. Twenty-six pupils at the Strand School, however, had nationalities of origin of which there were in each case fewer than five; they were therefore not identified. The Strand school thus presented an especially difficult case. It was assumed that the Muslim/non-Muslim ratio of these 26 pupils corresponded to the general national ratio of unidentified Muslim/non-Muslim pupils. An alternative approach, using the Muslim/non-Muslim ratio of each particular school, was tried but rejected, as it tended to overstate the total number of pupils with Muslim backgrounds. This is because detailed data concerning nationalities identified as non-Muslim is more likely to be suppressed than detailed data concerning nationalities identified as Muslim: pupils of non-Danish origin with Muslim backgrounds come in relatively large numbers from a relatively small number of countries (such as Turkey), while pupils of non-Danish origin with non-Muslim backgrounds come in relatively small numbers from a relatively large number of countries (such as the United States). The use of an assumption inevitably reduced accuracy somewhat, but had most impact on pupils of non-Danish origin and non-Muslim background. These, however, are not the subject of this research note.

In all, then, one source of inaccuracy overstates Muslim background, another understates it, and the third has no impact overall but reduces accuracy of data somewhat for analysis by particular school, especially with regard to a type of pupil with which this research note is not concerned. These problems with the data for this research note, then, to some extent cancel one another out. They reduce overall precision somewhat. Their impact cannot be quantified precisely, but it is unlikely to be significant.

\section{National Picture}

Data for the school year 2008-09 shows that 10 per cent of all pupils in state schools and free schools had a non-Danish origin, of whom 7 per cent had a Muslim background, as shown in Table 1 below. This overall national picture, however, is of limited significance, as there were very significant differences from school to school, producing very different experiences for particular schools and pupils, as discussed below. 
Table 1: Pupils by background

\begin{tabular}{|c|c|c|c|c|c|c|}
\hline \multirow{2}{*}{ Background } & \multicolumn{2}{|c|}{ State schools } & \multicolumn{2}{|c|}{ Free schools } & \multicolumn{2}{|c|}{ All schools } \\
\hline & $\%$ & pupils & $\%$ & pupils & $\%$ & pupils \\
\hline Muslim & 7 & 43,355 & 6 & 5,774 & 7 & 49,129 \\
\hline Other & 3 & 15,613 & 4 & 3,774 & 3 & 19,387 \\
\hline Non-Danish & 10 & 58,968 & 10 & 9,548 & 10 & 68,516 \\
\hline Danish & 90 & 520,669 & 90 & 86,383 & 90 & 607,052 \\
\hline All & 100 & 579,637 & 100 & 95,931 & 100 & 675,568 \\
\hline
\end{tabular}

National origins of pupils with Muslim backgrounds were diverse, with no single origin predominating. Pupils of Arab origin were the single largest group, especially in free schools, where they came close to making up half the pupils from Muslim backgrounds, as Table 2 shows. Turks were the second largest group, followed by pupils from South Asia (Pakistan, India, and Bangladesh) and Afghanistan. Pupils of Balkan origin, identified by the ministry mostly as Yugoslav or Bosnian, can generally be assumed to be of Bosnian origin, as many Bosnian refugees moved to Denmark, while few Serbs or Croats did. Some 9 per cent were from the Horn of Africa, mostly Somalia. These figures, incidentally, help predict the future ethnic composition of the Danish national population.

\section{Table 2: Pupils with Muslim religio-cultural background by national origin}

\begin{tabular}{|c|c|c|c|c|c|c|}
\hline & \multicolumn{2}{|c|}{ State schools } & \multicolumn{2}{|c|}{ Free schools } & \multicolumn{2}{|c|}{ All schools } \\
\hline & $\%$ & pupils & $\%$ & pupils & $\%$ & pupils \\
\hline Arab & 35 & 15,349 & 43 & 2,498 & 37 & 17,655 \\
\hline Turkish & 23 & 10,028 & 22 & 1,278 & 24 & 11,306 \\
\hline S. Asia \& Afghan & 14 & 6,136 & 10 & 591 & 13 & 6,289 \\
\hline Balkan & 16 & 6,788 & 4 & 252 & 13 & 6,057 \\
\hline Horn of Africa & 9 & 3,881 & 10 & 561 & 9 & 4,377 \\
\hline Iranian & 4 & 1,550 & 5 & 298 & 4 & 1,848 \\
\hline \multirow[t]{2}{*}{ Unknown ${ }^{4}$} & & -377 & & 296 & & \\
\hline & $100^{5}$ & 43,355 & 100 & 5,774 & 100 & 47,532 \\
\hline
\end{tabular}

${ }^{4}$ That "unknown" is negative for state schools in table 2 reflects the consequences of the method used to compensate for the Ministry's suppression of detailed data relating to groups of pupils smaller than five, discussed above

${ }^{5}$ Percentages do not always add up to $100 \%$ because of rounding. 
As Table 2 indicates, different groups made different degrees of use of free schools in this period. As Table 3 shows, 14 per cent of pupils of Danish origin were in free schools. Families of Iranian, EU and North American origin made more frequent use of free schools than did families of Danish origin. Almost one-third of pupils with a national origin in an EU or North American state were in free schools, often either German or international ones. Families of Arab origin made about as much use of free schools as families of Danish origin did, but other Muslim-origin families made less use. Only 4 per cent of pupils of Balkan (Bosnian) origin were in free schools.

Table 3: Pupils in free schools/all schools, by origin

$\begin{array}{lrr} & \% & \text { Pupils } \\ \text { EU \& N. America } & 27 & 1,711 / 6,351 \\ \text { Other non-Muslim } & 18 & 1,650 / 9,396 \\ \text { Iranian } & 16 & 298 / 1,848 \\ \text { Danish origin } & 14 & 86,383 / 607,052 \\ \text { Arab } & 14 & 2,498 / 17,655 \\ \text { Horn of Africa } & 13 & 561 / 4,377 \\ \text { Turkish } & 11 & 1,278 / 11,306 \\ \text { S. Asia \& Afghan } & 9 & 591 / 6,289 \\ \text { Balkan } & 4 & 252 / 6,057\end{array}$

Once again, however, this overall national picture is of limited significance, as there were very significant differences from school to school. Families of Danish and Arab origin make comparable use of free schools, but, as we will see below, they use different free schools.

\section{From the School's Perspective}

The vast majority of Danish schools have few or no pupils of Muslim background, as Table 4 shows. In all, 76 per cent of Danish schools (and 73 per cent of state schools) have a Muslim-background population of less than 5 per cent. Thirty-five per cent of schools $(30$ per cent of state schools) in fact have no pupils of Muslim background at all. One way of understanding the impact of a 5 per cent Muslim-background population is that it would mean an average of 1.5 Muslim-background pupils in an average class of 30 . This would have little impact on the nature of the class.

There are, however, a number of schools with Muslim background populations greater than 5 per cent. Nineteen per cent of schools have a Muslim background population of between 5.1 per cent and 25 per cent. Most of these are state schools: relatively few free schools fall into this category, as free schools generally have either a very small Muslimbackground population or a very large one. Six per cent of Danish 
schools have a Muslim-background population of more than 25 per cent. Two per cent actually have a Muslim-background majority ( 2 per cent of state schools, 5 per cent of free schools). These fall into two categories. Most free schools with a Muslim-background majority have a Muslimbackground population of over 75 per cent, while most state schools with a Muslim-background majority have a Muslim-background population under 75 per cent. It can be assumed that the free schools in question intend to have a generally Muslim population, while the state schools do not.

Table 4: Numbers of schools by percentage of pupils with a Muslim religio-cultural background

\begin{tabular}{|c|c|c|c|c|c|c|}
\hline \multirow{2}{*}{$\begin{array}{l}\text { Muslim- } \\
\text { background } \\
\text { pupils }\end{array}$} & \multicolumn{2}{|c|}{ State schools } & \multicolumn{2}{|c|}{ Free schools } & \multicolumn{2}{|c|}{ All schools } \\
\hline & $\%$ & schools & $\%$ & schools & $\%$ & schools \\
\hline $0 \%$ & 30 & 454 & 54 & 270 & 35 & 724 \\
\hline $0.1 \%-5 \%$ & 43 & 664 & 33 & 166 & 41 & 830 \\
\hline $5.1 \%-10 \%$ & 11 & 169 & 5 & 27 & 10 & 196 \\
\hline $10.1 \%-15 \%$ & 4 & 64 & 2 & 8 & 4 & 72 \\
\hline $15.1 \%-20 \%$ & 4 & 56 & 0 & 1 & 3 & 57 \\
\hline $20.1 \%-25 \%$ & 2 & 36 & 0 & 2 & 2 & 38 \\
\hline $0 \%-25 \%$ & 94 & 1,443 & 94 & 474 & 94 & 1,917 \\
\hline $25.1 \%-50 \%$ & 4 & 66 & 1 & 4 & 3 & 70 \\
\hline $50.1 \%-75 \%$ & 1 & 20 & 1 & 5 & 1 & 25 \\
\hline \multirow[t]{2}{*}{$75.1 \%-100 \%$} & 1 & 8 & 4 & 20 & 1 & 28 \\
\hline & 100 & 1,537 & 100 & 503 & 100 & 2,040 \\
\hline
\end{tabular}

The Muslim-majority school is thus an extreme rarity in Denmark. The vast majority of schools have very small Muslim-background populations. For the pupil with a Muslim background, however, the Muslim-majority school is less of a rarity.

\section{From the Pupil's Perspective}

Most pupils of Danish origin attend schools with few or no pupils of Muslim background; but many pupils with a Muslim background attend schools with a significant Muslim presence, as Table 5 shows. Seventyone per cent of pupils of Danish origin attend schools of the type identified above as the norm: that is to say, schools with 5 per cent or fewer Muslim-background pupils. Only 14 per cent of pupils with Muslim background attend schools of this type, however. About half of pupils with Muslim backgrounds attend unusual schools with Muslimbackground populations of between 10 and 50 per cent, a type of school attended by only 14 per cent of pupils of Danish origin. Twenty-two per cent of pupils with a Muslim background attend Muslim-majority 
schools, an experience they share with only 0.5 per cent of pupils of Danish origin. And, as has been said, some of those Danish-origin pupils can be assumed to be being brought up in Muslim families, despite their Danish origin. Danish origin and Muslim background can coexist.

\section{Table 5: Pupils by type of school}

\begin{tabular}{|c|c|c|c|c|}
\hline \multirow{3}{*}{$\begin{array}{l}\text { Muslim- } \\
\text { background } \\
\text { pupils }\end{array}$} & \multicolumn{4}{|c|}{ Attended by pupils with } \\
\hline & \multicolumn{2}{|c|}{ Danish origins } & \multicolumn{2}{|c|}{$\begin{array}{c}\text { Muslim } \\
\text { backgrounds }\end{array}$} \\
\hline & $\%$ & pupils & $\%$ & pupils \\
\hline $0 \%-5 \%$ & 71 & 431,968 & 14 & 7,080 \\
\hline $5.1 \%-10 \%$ & 14 & 87,343 & 14 & 6,902 \\
\hline $10.1 \%-50 \%$ & 14 & 84,614 & 50 & 24,525 \\
\hline \multirow[t]{2}{*}{$50.1 \%-99 \%$} & 1 & 3,126 & 22 & 10,622 \\
\hline & 100 & 607,052 & 100 & 49,129 \\
\hline
\end{tabular}

Seen somewhat differently, only 14 per cent of Muslim-background pupils experience what might be called a very Danish school (one where Muslim-background pupils are 5 per cent or less), and only 15 per cent of Danish-origin pupils experience what might be called a very Muslim school (one where Muslim-background pupils are over 10 per cent).

Tables 6 and 7 provide detailed analysis of the types of school attended by pupils with Muslim and non-Muslim backgrounds. As stated above, it may be assumed in the case of Muslim-majority free schools that the decisive factor is parental choice. In the case of state schools, however, the picture probably reflects residential clustering more than parental choice. It should, however, be remembered that residential clustering can also reflect choice. People generally like to live with other people who they feel are like them. 
Table 6: Pupils with Muslim backgrounds by type of school

\begin{tabular}{|c|c|c|c|c|c|c|}
\hline \multirow{2}{*}{$\begin{array}{l}\text { Muslim- } \\
\text { background } \\
\text { pupils }\end{array}$} & \multicolumn{4}{|c|}{$\begin{array}{c}\text { Pupils attending } \\
\text { Free schools } \\
\end{array}$} & \multicolumn{2}{|c|}{ All schools } \\
\hline & $\%$ & pupils & $\%$ & pupils & $\%$ & pupils \\
\hline $0 \%-5 \%$ & 14 & 6,127 & 17 & 952 & 14 & 7,080 \\
\hline $5.1 \%-10 \%$ & 15 & 6,285 & 11 & 618 & 14 & 6,902 \\
\hline $10.1 \%-15 \%$ & 9 & 4,073 & 6 & 325 & 9 & 4,398 \\
\hline $15.1 \%-20 \%$ & 12 & 5,068 & 1 & 48 & 10 & 5,116 \\
\hline $20.1 \%-25 \%$ & 10 & 4,222 & 2 & 137 & 9 & 4,359 \\
\hline $0 \%-25 \%$ & 59 & 25,774 & 36 & 2,081 & 57 & 27,855 \\
\hline $25.1 \%-50 \%$ & 24 & 10,488 & 3 & 164 & 22 & 10,652 \\
\hline $50.1 \%-75 \%$ & 11 & 4,735 & 9 & 533 & 11 & 5,269 \\
\hline \multirow[t]{2}{*}{$75.1 \%-100 \%$} & 5 & 2,357 & 52 & 2,995 & 11 & 5,353 \\
\hline & 100 & 43,355 & 100 & 5,774 & 100 & 49,129 \\
\hline
\end{tabular}

Table 7: Pupils of Danish origin by type of school

\begin{tabular}{|c|c|c|c|c|c|c|}
\hline \multirow{2}{*}{$\begin{array}{l}\text { Muslim- } \\
\text { background } \\
\text { pupils }\end{array}$} & \multicolumn{6}{|c|}{ Pupils attending } \\
\hline & $\%$ & pupils & $\%$ & pupils & $\%$ & pupils \\
\hline $0 \%$ & 15 & 75,686 & 36 & 31,245 & 8 & 106,931 \\
\hline $0.1 \%-5 \%$ & 54 & 279,965 & 52 & 45,072 & 54 & 325,037 \\
\hline $5.1 \%-10 \%$ & 15 & 80,102 & 8 & 7,242 & 14 & 87,343 \\
\hline $10.1 \%-15 \%$ & 5 & 27,347 & 2 & 1,779 & 5 & 29,126 \\
\hline $15.1 \%-20 \%$ & 4 & 22,538 & 0 & 182 & 4 & 22,720 \\
\hline $20.1 \%-25 \%$ & 3 & 13,514 & 0 & 215 & 2 & 13,729 \\
\hline $0 \%-25 \%$ & 96 & 499,151 & 99 & 85,734 & 96 & 584,886 \\
\hline $25.1 \%-50 \%$ & 4 & 18,854 & 0 & 186 & 3 & 19,040 \\
\hline $50.1 \%-75 \%$ & 1 & 2,384 & 0 & 144 & 0 & 2,528 \\
\hline $75.1 \%-100 \%$ & 0 & 279 & 0 & 319 & 0 & 599 \\
\hline & 100 & 520,669 & 100 & 86,383 & 100 & 607,052 \\
\hline
\end{tabular}

\section{Conclusion}

Even though religio-cultural background as determined by nationality of origin is not the same as religion, and even though many other factors intervene and are important, the figures reported in this note still tell us something important about the Danish school system and the experiences of those in it: of teachers or pupils, of Danish or non- 
Danish origin, and of non-Muslim or Muslim background. The free school system contains mostly very Danish schools or very Muslim schools, with not much in between. State schools are more mixed, but even so most state schools have few Muslim-background pupils. Those that have Muslim-background majorities are rarities, interesting and important in themselves, but with little impact on the state school system as a whole or on pupils of Danish origin. Where they do have an impact is on pupils of Muslim background, who for the most part experience a different school system to that experienced by pupils of Danish origin.

\section{About the Author}

Mark Sedgwick is professor of Arab and Islamic studies at Aarhus University. He works on modern and contemporary Islam in Europe and in the Middle East, and on related topics. His latest book is an edited collection, Making European Muslims: Religious Socialization among Young Muslims in Scandinavia and Western Europe (New York: Routledge, 2014). 